\title{
Meningkatkan Perilaku Kinerja Pegawai Melalui Pengaruh Kepemimpinan, Lingkungan Kerja Dan Kompetensi
}

\author{
Darmaesti \\ Sekolah Tinggi Pariwisata Sahid Surakarta \\ Email: darmaesti2@gmail.com
}

\begin{abstract}
The development of an organization is strongly supported by the presence of human resources. The realization of organizational goals cannot be separated from the active role of humans who plan, carry out and determine the activities of the organization. The goals of an organization are unlikely to be realized if there is no active role of employees in operating the infrastructure owned by the organization. The success in achieving organizational goals is due to the good performance of employees. The performance of employees will increase if the abilities of the employees in the organization are growing. The purpose of this study was to determine the effect of leadership, work environment and competence on performance with the intervening variable job satisfaction. All employees of the Sahid Surakarta High School of Tourism as many as 30 respondents were sampled in this study. The path analysis regression model was used in this study. After conducting the research, the results show that leadership and work environment have a positive and insignificant effect on job satisfaction and employee performance, competence has a positive and significant effect on job satisfaction and employee performance, and job satisfaction has a negative and insignificant effect on the performance of employees of the Sahid Tourism College. Surakarta. To improve employee performance, the leadership should pay attention to competency factors so that the organization can achieve its vision and mission.
\end{abstract}

Keywords: employee performance, leadership, work environment, and competence.

\section{Abstrak}

Berkembangnya suatu organisasi sangat didukung dengan adanya sumber daya manusia. Terwujudnya tujuan organisasi tidak lepas dari peran aktif manusia yang merencanakan, melakukan dan menentukan kegiatan dari organisasi tersebut. Tujuan dari suatu organisasi kecil kemungkinan untuk diwujudkan jika tidak ada peran aktif pegawai dalam mengoperasionalkan sarana prasarana yang dimiliki organisasi. Keberhasilan untuk tercapainya tujuan organisasi karena kinerja yang baik dari pegawai. Kinerja para pegawai akan semakin meningkat jika kemampuan yang dimiliki para pegawai dalam organisasi semakin berkembang. Tujuan diadakannya penelitian ini untuk mengetahui pengaruh dari kepemimpinan, lingkungan kerja dan kompetensi terhadap kinerja dengan variabel intervening kepuasan kerja. Seluruh pegawai Sekolah Tinggi Pariwisata Sahid Surakarta sebanyak 30 responden dijadikan sampel dalam penelitian ini. Model regresi analisis jalur digunakan dalam penelitian ini. Setelah diadakan penelitian menunjukkan hasil bahwa kepemimpinan dan lingkungan kerja mempunyai pengaruh positif dan tidak signifikan terhadap kepuasan kerja dan kinerja pegawai, kompetensi berpengaruh positif dan signifikan terhadap kepuasan kerja dan kinerja pegawai, dan kepuasan kerja berpengaruh negatif dan tidak signifikan terhadap kinerja pegawai Sekolah Tinggi Pariwisata Sahid Surakarta. Untuk meningkatkan kinerja pegawai, sebaiknya pimpinan memperhatikan faktor kompetensi sehingga organisasi dapat mencapi visi dan misinya.

Kata kunci: kinerja pegawai, kepemimpinan, lingkungan kerja, dan kompetensi.

\section{PENDAHULUAN}

Sumber Daya Manusia merupakan modal utama dari pembangunan suatu bangsa. Dan faktor utama untuk memajukan kesejahteraan bangsa juga tergantung dari SDM yang ada. Terwujudnya tujuan dari organisasi merupakan hasil dari peran aktif manusia yang ada di dalam organisasi tersebut karena mereka yang merencanakan, melakukan dan menentukan tujuan organisasi. Dengan demikian tujuan organisasi dapat terwujud atas keaktifan para pegawai menggunakan peralatan canggih yang telah dimiliki organisasi.

Berkembangnya organisasi sangat didukung dengan adanya sumber daya manusia yang tersedia. Berhasilnya organisasi mencapai tujuan tersebut sangat dipengaruhi oleh kinerja para pegawainya. Semakin tinggi tingkat kemampuan yang dimiliki pegawai maka semakin bertambah baik kinerjanya dalam organisasi. Demikian juga sebaliknya, jika semakin rendah kemampuan yang dimiliki pegawai, maka semakin rendah kinerjanya dalam suatu organisasi. 
Agar aktifitas manajemen suatu organisasi berjalan dengan baik, maka organisasi harus memiliki pegawai yang berkompeten atau memiliki kemampuan yang tinggi untuk mengelola organisasi dengan baik sehingga kinerja pegawai meningkat. Dengan pengelolaan sumber daya manusia yang baik oleh suatu organisasi dan untuk tercapainya tujuan perusahaan dapat ditempuh oleh seorang pimpinan dengan meningkatkan mental bekerja yang lebih baik untuk pegawai dengan loyalitas dan dedikasi yang tinggi terhadap pekerjaannya, memberikan bimbingan dan pengarahan, memberikan motivasi dalam bekerja serta melakukan koordinasi yang lebih baik dalam bekerja. Karena penanganan sumber daya manusia yang tepat akan menjadikan organisasi semakin dinamis dan berkembang.

Definisi dari kinerja merupakan hasil pekerjaan yang telah dicapai oleh seorang pegawai yang secara kualitas dan kuantitas dalam melaksanakan pekerjaannya sesuai dengan tanggungjawab yang telah diberikan kepadanya (Mangkunegara, 2007). Menurut Sedarmayanti (2008) kinerja adalah hasil kerja yang telah dicapai oleh kelompok atau seseorang dalam suatu organisasi dalam rangka upaya mencapai tujuan organisasi yang bersangkutan secara resmi, sesuai moral dan etika dan tidak melanggar hukum yang berlaku serta disesuaikan dengan wewenang dan tanggungjawabnya.

Kinerja juga merupakan suatu tindakan atau pelaksanaan tugas yang telah diselesaikan dalam kurun waktu tertentu. Dan proses yang telah dirancang agar tujuan organisasi dengan tujuan individu dapat terhubung dan tujuan dapat bertemu dinamakan manajemen kinerja.

Kondisi yang tidak dapat dihindari dan harus dikedepankan oleh suatu organisasi adalah adanya pelayanan yang semakin ditingkatkan dan pemenuhan tuntutan masyarakat. Kompetensi dan pertanggungjawaban birokrasi sangat dibutuhkan. Dengan adanya pengelolaan sumber daya manusia yang tepat dalam organisasi atau perusahaan, diharapkan dapat meningkatkan kinerja pegawai. Karena pada hakekatnya sumber daya manusia dalam suatu organisasi saling membutuhkan, sedangkan pegawai adalah modal utama yang terpenting pada organisasi dimana para pegawai menjadi perencana dan pelaku aktif dari setiap aktivitas organisasi.

Dengan paparan tersebut maka penelitian ini mengkaji kinerja pegawai di Sekolah Tinggi Pariwisata Sahid Surakarta. Kinerja pegawai penting untuk mencapai visi dari Sekolah Tinggi Pariwisata Sahid Surakarta yaitu pada tahun 2025 menuju program studi unggulan di bidang kepariwisataan dengan berbasis kepada nilai-nilai kewirausahaan, sedangkan misinya 1) dengan pengelolaan yang baik dan benar menjadikan salah satu program studi pariwisata yang mampu menghadapi persaingan dalam manajemen mutu, 2) mendukung perkembangan yang berkesinambunngan dengan struktur finansial yang mantap 3) dengan ciri dan sifat sebagai knowledge and skill base hotelier yang dimiliki mampu menciptakan dan mengembangkan insan profesional di bidang pariwisata yang selalu dapat menciptakan masa depan 4) bagi masyarakat pelaku pariwisata dapat menjadikan pusat pengetahuan kreatif. Dengan visi dan misi yang telah ditetapkan Sekolah Tinggi Pariwisata Sahid Surakarta maka diharapkan tujuan dapat tercapai yaitu: a) Dapat menghasilkan lulusan yang memiliki wawasan kebangsaan yang menitikberatkan pada aspek nasionalisme - religius yang dinamis. b) Menghasilkan lulusan yang mempunyai pengetahuan dan ketrampilan yang ditunjang dengan akhlak yang benar dan kuat dengan norma-norma kebersamaan, jujur, rendah hati, bersikap terbuka dan tanggap terhadap masalah-masalah dalam masyarakat serta kemajuan yang terjadi dalam masyarakat serta kemajuan yang terjadi dalam pengetahuannya. c) Lulusan yang dihasilkan mampu menerapkan pengetahuan yang dikuasainya dalam kegiatan-kegiatan produktif dan pelayanan pada masyarakat. d) Lulusan yang dihasilkan memiliki kemampuan untuk merumuskan pendekatan penyelesaian berbagai masalah masyarakat dengan penalaran ilmiah. e) Lulusan yang dihasilkan memiliki sifat-sifat yang unggul berbudaya sehingga mampu bertahan dan mampu menciptakan masa depan.

Salah satu faktor penting seorang pegawai dalam bekerja adalah dapat menikmati kepuasan hidup setelah mendapatkan hasil yang memuaskan dari pekerjaannya. Setiap manusia akan memiliki ukuran 
kepuasan yang tidak sama karena masing-masing mempunyai sistem nilai yang ditentukan sendiri dalam dirinya. Dengan semakin banyaknya kegiatan dalam pekerjaan yang dapat diselesaikan tepat waktu sesuai target individu, maka akan semakin tinggi tingkat kepuasan yang dirasakan, demikian juga sebaliknya semakin sedikit kegiatan dalam pekerjaan yang dapat diselesaikan tepat waktu dan tidak sesuai target individu, maka akan semakin rendah tingkat kepuasan yang dirasakan.

Kepuasan kerja dapat dinikmati di dalam pekerjaan, di luar pekerjaan dan kombinasi dalam dan luar pekerjaan. Kepuasan kerja menurut Robbins (1996) merupakan suatu sikap yang umum dari seorang individu terhadap pekerjaannya. Adanya interaksi dengan atasan, rekan kerja, peraturan dalam pekerjaan, standar kerja, kondisi kerja, kebijakan organisasi merupakan tuntutan dalam suatu pekerjaan. Jika tingkat kepuasan kerja seseorang tinggi, maka dia akan bersikap positif terhadap pekerjaan yang dilakukan. Dan sebaliknya akan menunjukkan sikap negatif terhadap kerja jika tidak puas dengan pekerjaannya.

Dalam perhitungan jika pendapatan yang diperoleh pegawai membuat kebutuhan hidupnya tercukupi dapat dikatakan pegawai tersebut mendapatkan kepuasan dalam pekerjaannya. Hal ini berarti pegawai dalam bekerja merasakan nyaman dan tidak ada kekhawatiran lainnya, misal gaji yang diterima tidak cukup, jaminan kesehatan/keselamatan kerja tidak diberikan dan tidak adanya jaminan masa tua atau pensiun.

Teori hubungan variabel kepuasan kerja yang mempunyai kesenjangan dengan kinerja, serta kesenjangan antara temuan hasil penelitian, menimbulkan keinginan untuk mengkaji lebih dalam hubungan antara pengaruh kepuasan kerja dengan kinerja pegawai. Berdasarkan teori tersebut maka perlu dilakukan penelitian untuk menguji kembali pengaruh kepuasan kerja terhadap kinerja pegawai Sekolah Tinggi Pariwisata Sahid Surakarta.

Kepemimpinan dapat didefinisikan sebagai suatu kepribadian yang mendatangkan keinginan suatu kelompok untuk menirunya atau mengikutinya, atau menimbulkan pengaruh tertentu sebagai suatu kewibawaan yang membuat kelompok orang melakukan perbuatan yang dikehendaki (Karyadi, 2010). Peranan kepemimpinan dalam organisasi ada tiga bentuk yaitu peranan sebagai pengambil keputusan, peranan yang bersifat interpersonal dan peranan yang bersifat informasional.

Kemampuan dengan menggunakan kekuasaan untuk mempengaruhi berbagai perilaku anggota melalui berbagai upaya merupakan definisi dari kepemimpinan menurut Ambar (2004), sedangkan menurut Kartono (2005) definisi dari kepemimpinan sebagai aktivitas untuk membuat orang lain terpengaruh sehingga bersedia melakukan kerjasama dan tujuan yang diinginkan dapat terwujud. Menurut Handoko (2002) kepemimpinan merupakan suatu bentuk kegiatan dimana kegiatan tersebut saling berkaitan satu sama lain walaupun kegiatan tersebut tidak sesuai dengan yang telah ditentukan. Kegiatannya merupakan rangkaian yang berisi mengaktifkan, mengarahkan, memandu dan memantau orang lain untuk melakukan aktivitas secara mandiri atau bersama-sama. Kegiatan-kegiatan yang dilakukan sebagai upaya untuk membuat orang lain terpengaruh perasaannya, pikirannya dan tingkah lakunya ke arah tercapaiannya tujuan organisasi, sehingga hubungan seorang pimpinan organisasi dengan anggota kelompok yang dipimpin membuat seseorang atau kelompok tersebut melakukan sesuatu sesuai dengan keinginan pimpinan disebut kepemimpinan.

Suprapta, Sintaasih dan Riana (2015) melakukan penelitian yang menunjukkan bahwa dari kepemimpinan ada pengaruh signifikan terhadap Kepuasan Kerja. Hasil penelitian yang dilakukan oleh Irvianti, Prabowo dan Permana (2012) menunjukkan bahwa kepemimpinan berpengaruh tidak signifikan terhadap Kepuasan Kerja. Hasil penelitian yang dilakukan oleh Hardhiansyah dan Suprihadi (2016) menunjukkan bahwa kepemimpinan berpengaruh signifikan pada kinerja. Hasil penelitian yang dilakukan oleh Nurwati, Nimram, Setiawan dan Surachman (2012) menunjukkan bahwa kepemimpinan berpengaruh tidak signifikan terhadap kinerja. 
Faktor dari lingkungan kerja juga mempunyai pengaruh dengan kinerja pengawai. Nitisemito (2000) berpendapat bahwa semua yang berada di sekitar pekerja yang mempengaruhi dalam menjalankan aktivitas pekerjaan disebut lingkungan kerja.

Lingkungan kerja dalam suatu organisasi tidak melaksanakan proses produksi tetapi lingkungan kerja mempunyai pengaruh langsung terhadap pegawai yang sedang melaksanakan proses produksi tersebut. Kinerja pegawai dapat ditingkatkan dengan menciptakan lingkungan kerja yang nyaman di Sekolah Tinggi Pariwisata Sahid Surakarta. Suatu organisasi harus menyediakan lingkungan kerja fisik dan non fisik yang memadai bagi karyawannya seperti tata ruang kantor yang nyaman, lingkungan yang bersih, pertukaran udara yang baik, warna dinding yang membuat nyaman, penerangan yang cukup, suasana kerja, kesejahteraan, hubungan yang baik antar sesama pegawai, hubungan yang baik antar pegawai dengan pimpinan, serta tersedianya tempat ibadah. Menurut Sedarmayati (2001) lingkungan kerja yang baik dapat mendukung pelaksanaan kerja sehingga karyawan memiliki semangat bekerja dan dapat meningkatkan kinerja karyawan.

Hasil penelitian yang dilakukan oleh Wibowo (2014) menunjukkan bahwa Lingkungan kerja berpengaruh signifikan terhadap Kepuasan Kerja. Hasil penelitian yang dilakukan oleh Dhermawan, Sudibya, dan Utama (2012) menunjukkan bahwa Lingkungan kerja berpengaruh tidak signifikan terhadap Kepuasan Kerja. Hasil penelitian yang dilakukan oleh Pramana dan Sudarma (2013) menunjukkan bahwa lingkungan kerja berpengaruh signifikan pada kinerja. Sahlan, Mekel dan Trang (2015) telah melakukan penelitian bahwa lingkungan kerja dan kinerja berpengaruh tidak signifikan.

Dalam suatu organisasi kompetensi karyawan juga menjadi faktor yang diperhitungkan dalam menilai kinerja karyawan. Dengan penetapan kompetensi dapat memperjelas standar kerja dan tujuan suatu organisasi yang ingin dicapai dan dapat menentukan nilai yang harus menjadi fokus kerja karyawan.

Menurut Edi Suswardji (2012) dengan adanya kompetensi dapat menjadi landasan yang kuat untuk mencapai keberhasilan organisasi baik bagi pemimpin, karyawan maupun organisasi sendiri. Dengan demikian dapat diketahui bahwa untuk mencapai tujuan organisasi yang lebih baik lagi hal yang penting adalah kompetensi. Kompetensi menyangkut kemampuan dasar seseorang untuk melakukan pekerjaan sehingga kompetensi mempunyai peranan yang sangat penting (Moeheriono, 2009).

Penelitian yang dilakukan oleh Dhermawan, Sudibya, dan Utama (2012) menunjukkan bahwa Kompetensi berpengaruh signifikan terhadap Kepuasan Kerja. Hasil penelitian yang dilakukan Parmin (2017) menunjukkan bahwa Kompetensi berpengaruh tidak signifikan terhadap Kepuasan Kerja. Hasil penelitian yang dilakukan oleh Posuma (2013) menunjukkan bahwa kompetensi berpengaruh signifikan pada kinerja. Dan hasil penelitian dari Dhermawan, Sudibya, dan Utama (2012) ditunjukkan bahwa kompetensi berpengaruh tidak signifikan terhadap kinerja.

Berdasarkan latarbelakang yang telah diuraikan di atas maka perlu diadakan penelitian dengan mengambil obyek pegawai Sekolah Tinggi Pariwisata Sahid Surakarta, dengan analisis regresi intervening dan diharapkan bisa berguna sebagai bahan masukan bagi peneliti yang akan datang serta bagi manajemen dalam upaya meningkatkan kinerja pegawai di Lingkungan Sekolah Tinggi Pariwisata Sahid Surakarta.

\section{METODE PENELITIAN}

Tiga puluh orang pegawai Sekolah Tinggi Pariwisata Sahid Surakarta menjadi populasi dan sampel dalam penelitian ini. Sedangkan teknik dalam mengumpulkan data penelitian menggunakan observasi dan kuesioner:

a. Observasi merupakan cara untuk mendapatkan informasi dan data penelitian yang berupa obyek maupun subyek yang bersangkutan yaitu melalui pengamatan langsung di lapangan. 
b. Kuesioner berisi tentang daftar pertanyaan yang ada kaitannya dengan penelitian yang sedang dilakukan. Kuesioner ini diberikan kepada responden yang isinya berhubungan dengan kepemimpinan, lingkungan kerja, kompetensi, kepuasan kerja dan juga kinerja.

Dalam penelitian ini teknik analisis data yang digunakan:

- dengan pengujian instrumen

a. Uji validitas: ditunjukkan sejauh mana keakuratan dan ketelitian dari kegunaan suatu alat pengukuran per variabel. Jika tingkat validitas semakin tinggi maka varian kesalahan semakin rendah. Dapat dikatakan valid jika hasilnya $r_{\text {hitung }}>r_{\text {tabel. }}$ Uji Validitas memerlukan teknik yaitu one shot method dimana dengan menggunakan perbandingan nilai dari $r_{\text {hitung }}$ dan $r_{\text {tabel }}$ sebesar 0,349 dan dapat dikatakan valid jika $r_{\text {hitung }}>r_{\text {tabel }}$.

b. Uji reliabilitas merupakan tingkat ukuran dari kestabilan maupun kemantapan suatu alat ukur yaitu kuesioner. Jika pengukuran terhadap suatu kuesioner yang dilakukan berulang dan selalu memberikan hasil yang tidak berubah-ubah dapat dikatakan stabil, dengan syarat semua kondisi tidak terjadi perubahan.

Uji Reliabilitas terhadap penelitian ini menggunakan teknik pengukuran Cronbach's Alpha, rumusnya adalah:

$$
\left.r_{\mathrm{i}}=\left[\frac{k}{k-1}\right] \mid 1-\frac{\Sigma \sigma_{5}^{a}}{\nu_{f}^{2}}\right\rfloor
$$

$$
\begin{aligned}
& \text { Keterangan: } \\
& \begin{array}{ll}
r_{i 1} & =\text { reliabilitas instrumen } \\
\mathrm{k} & =\text { banyaknya butir pemyataan } \\
\Sigma \sigma_{*}^{2} & =\text { jumlahi varians bulir } \\
\sigma_{i}^{2} & \text { - varians total }
\end{array}
\end{aligned}
$$

Apabila Cronbach's Alpha mempunyai tingkatan lebih besar (>) dari 0,60 maka hasilnya reliabel (Ghozali, 2004: 24).

c. Uji linieritas: digunakan untuk menunjukkan suatu distribusi dari data penelitian statusnya linier atau tidak linier. Dengan hasil yang didapat dari pengujian linieritas maka akan dapat ditentukan teknik dari analisis regresi yang digunakan. Analisis regresi linier dapat digunakan jika hasil dari uji linieritas merupakan data linier. Dan sebaliknya analisis regresi non linier akan digunakan jika hasil uji linieritas merupakan data yang tidak linier. Uji Linieritas, bertujuan untuk mendapatkan nilai $\mathrm{C}^{2}$ hitung atau ( $\mathrm{n} \mathrm{R}^{2}$ ).

\section{- dengan Analisis Jalur (path analysis) \\ a. Persamaan Regresi I (sub struktur I)$$
\mathrm{Y}_{1} \quad=\beta_{1} \mathrm{X}_{1}+\beta_{2} \mathrm{X}_{2}+\beta_{3} \mathrm{X}_{3}+\mathrm{e}_{1}
$$ \\ b. Persamaan Regresi II (sub struktur II) \\ $\mathrm{Y}_{2}=\beta_{1} \mathrm{X}_{1}+\beta_{2} \mathrm{X}_{2}+\beta_{3} \mathrm{X}_{3}+\beta_{4} \mathrm{Y}_{1}+\mathrm{e}_{2}$}


c. Pengaruh langsung, pengaruh tidak langsung dan pengaruh total

Pengaruh langsung didapatkan jika variabel independen ke variabel dependen tanpa melalui variabel dependen yang lain, sedangkan variabel yang melalui variabel lain atau variabel intervening disebut pengaruh tidak langsung, dan yang dimaksud dengan pengaruh total adalah hasil dari penjumlahan pengaruh langsung dan pengaruh tidak langsung

- Uji t, dilakukan agar dapat diketahui signifikan atau tidak signifikan pengaruh variabel independen secara parsial terhadap variabel dependen hal ini dapat dilihat melalui perbandingan nilai signifikansi terhadap nilai kesalahan (a). Dapat dikatakan bahwa penelitian yang dilakukan menggunakan tingkat signifikansi 0,05 atau sebesar 5\%. Hasil menunjukkan berpengaruh signifikansi jika signifikansi mempunyai nilai $<\mathrm{a}=0,05$.

- F test atau signifikansi F, digunakan untuk mengetahui signifikansi pengaruh variabel bebas terhadap variabel terikatnya secara simultan. Pada tabel ANOVA $^{\mathrm{b}}$ dalam output regresi SPSS versi 10 for windows dapat diketahui nilai signifikansi dari nilai F test. Program SPSS digunakan untuk keseluruhan dari pengolahan dan analisis data. Hasil menunjukkan berpengaruh signifikansi jika signifikansi mempunyai nilai $<\mathrm{a}=0,05$.

- Koefisien determinasi $\left(\mathrm{R}^{2}\right)$, diartikan sebagai suatu nilai yang menggambarkan total variasi variabel dependen dari suatu persamaan regresi. Besarnya variasi variabel dependen dapat dijelaskan oleh variabel independen, hal ini tercermin dari nilai koefisien determinasi. Variasi dari variabel dependen tidak dapat dijelaskan oleh variabel independen jika nilai dari koefisien determinasi sama dengan 0 (nol). Dan variasi dari variabel dependen dapat dijelaskan secara lengkap dan sempurna oleh variabel independen jika nilai dari koefisien determinasi sama dengan 1 (satu). Koefisien determinasi digunakan untuk mengetahui ukuran besarnya kontribusi dari variasi $X_{n}$ terhadap variabel $Y_{2}$, dan dapat digunakan untuk mendapatkan ketepatan dalam pendekatan terhadap analisis (Gujarati, 1997). $\mathrm{R}^{2}$ yang memiliki nilai berkisar $0 \leqq \mathrm{R}^{2} \leqq 1$ berarti mempunyai ketepatan dari regresi. Jika semakin besar nilai $\mathrm{R}^{2}$ artinya semakin tepat garis regresi linier dapat dipergunakan untuk pendekatan. Dan apabila nilai $\mathrm{R}^{2}$ sama dengan 1 (satu) dapat dikatakan bahwa pendekatannya tepat dan sempurna.

\section{HASIL DAN PEMBAHASAN}

Dari Hasil Uji Validitas didapatkan nilai $r_{\text {item }}>$ nilai $r_{\text {tabel }}$ sehingga dapat dikatakan valid.

Untuk hasil uji Reliabilitas karena Cronbach's Alpha > 0,6 dapat dikatakan bahwa dari seluruh variabel dalam keadaan yang reliabel. Uji linieritas memperlihatkan hasil nilai $\mathrm{R}^{2}$ sebesar 0,002 dengan sampel sejumlah 30 responden, maka didapatkan besarnya nilai $\mathrm{c}^{2}$ hitung adalah $30 \times 0,002=0,06$ dan nilai $\mathrm{c}^{2}$ tabel sebesar 40,12. jadi didapatkan nilai $\mathrm{c}^{2}$ hitung $<\mathrm{c}^{2}$ tabel.

Untuk analisis jalur path dengan persamaan regresi I: koefisien regresi variabel Kepemimpinan sebesar 0,215, artinya apabila lingkungan kerja dan kompetensi, tidak ada, besarnya peningkatan kepuasan kerja adalah konstanta ditambah 0,215; koefisien regresi variabel Lingkungan Kerja sebesar 0,066 artinya apabila kepemimpinan dan kompetensi tidak ada, besarnya peningkatan kepuasan kerja adalah konstanta ditambah 0,066 ; koefisien regresi variabel Kompetensi sebesar 0,673 artinya apabila kepemimpinan dan lingkungan kerja tidak ada, besarnya peningkatan kepuasan kerja adalah konstanta ditambah 0,673.

Untuk analisis jalur path dengan persamaan regresi II: koefisien regresi variabel Kepemimpinan sebesar 0,166 hal ini menunjukkan apabila lingkungan kerja, kompetensi dan kepuasan kerja tidak ada, besarnya peningkatan kinerja adalah konstanta ditambah 0,166 ; koefisien regresi variabel Lingkungan Kerja sebesar 0,280 artinya apabila Kepemimpinan, kompetensi dan kepuasan kerja tidak ada, besarnya peningkatan kinerja adalah konstanta ditambah 0,$280 ; 0,633$ ditunjukkan sebagai koefisien regresi variabel Kompetensi, artinya menunjukan apabila Kepemimpinan, lingkungan kerja dan kepuasan kerja tidak ada, maka besarnya peningkatan kinerja adalah konstanta ditambah 0,633 ; koefisien regresi variabel 
Kepuasan Kerja sebesar -0,275 artinya apabila Kepemimpinan, lingkungan kerja dan kompetensi tidak ada, besarnya penurunan kinerja adalah konstanta ditambah 0,275.

Dari hasil uji Koefisien Determinasi $\left(\mathrm{R}^{2}\right)$ persamaan pertama dalam penelitian ini didapatkan hasil sebesar 0,696; persamaan 2 dalam penelitian didapatkan hasil sebesar 0,470; dari persamaan 1 dan persamaan 2 tersebut didapatkan nilai koefisien determinasi total $\left(\mathrm{R}^{2}\right)$ sebesar 0,839 .

Berdasarkan analisis hasil Uji t persamaan pertama:

a) Variabel Kepemimpinan terhadap variabel Kepuasan Kerja

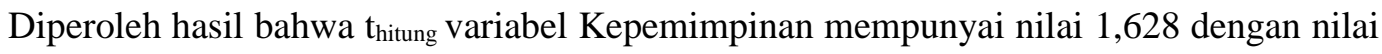
signifikan 0,115>0,05 hal ini berarti variabel Kepemimpinan mempunyai pengaruh tidak signifikan terhadap variabel Kepuasan Kerja, sehingga hipotesis 1 tidak terbukti

b) Variabel Lingkungan Kerja terhadap variabel Kepuasan Kerja

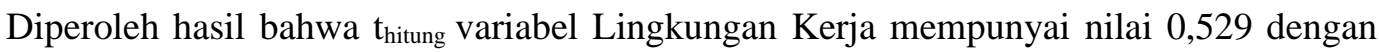
nilai signifikan 0,601 >0,05 hal ini berarti variabel Lingkungan Kerja mempunyai pengaruh tidak signifikan terhadap variabel Kepuasan Kerja, sehingga hipotesis 2 tidak terbukti

c) Variabel Kompetensi terhadap variabel Kepuasan Kerja

Diperoleh hasil bahwa thitung variabel Kompetensi mempunyai nilai 5,277 dengan nilai signifikan $0,000<0,05$ hal ini berarti variabel Kompetensi mempunyai pengaruh signifikan terhadap variabel Kepuasan Kerja, sehingga hipotesis 3 terbukti

Berdasarkan analisis hasil Uji t persamaan kedua:

a) Variabel Kepemimpinan terhadap variabel Kinerja

Hasil regresi menunjukkan nilai signifikan 0,382 >0,05 hal ini dapat diartikan bahwa variabel Kepemimpinan berpengaruh tidak signifikan terhadap variabel Kinerja, sehingga hipotesis 4 tidak terbukti

b) Variabel Lingkungan Kerja terhadap variabel Kinerja

Hasil regresi menunjukkan nilai signifikan $0,111>0,05$ hal ini dapat diartikan bahwa variabel Lingkungan Kerja berpengaruh tidak signifikan terhadap variabel Kinerja, sehingga hipotesis 5 tidak terbukti

c) Variabel Kompetensi terhadap variabel Kinerja

Hasil regresi menunjukkan nilai signifikan $0,017<0,05$ hal ini dapat diartikan bahwa variabel Kompetensi berpengaruh signifikan terhadap variabel Kinerja, sehingga hipotesis 6 terbukti.

d) Variabel Kepuasan Kerja terhadap variabel Kinerja

Hasil regresii menunjukkan nilai signifikan 0,307 > 0,05 ini dapat diartikan bahwa variabel kepuasan kerja mempunyai pengaruh tidak signifikan terhadap variabel kinerja sehingga hipotesis 7 tidak terbukti.

Hasil uji $\mathrm{F}$ dari persamaan pertama dapat diketahui bahwa besarnya nilai $\mathrm{F}=19,809$ signifikansi $0,000<0,05$. Dari hal tersebut dapat disimpulkan bahwa variable bebas mempengaruhi Kepuasan Kerja. Dan selanjutnya pada persamaan yang kedua diketahui besarnya nilai $F=5,545$ signifikansi $0,002<0,05$. Sehingga kesimpulannya dapat kita katakan variable bebas mempengaruhi Kinerja.

Total dari Nilai Koefisien Determinasi $\mathrm{R}^{2}$ sebesar 0,839 artinya pegawai di Sekolah Tinggi Pariwisata Sahid Surakarta dijelaskan bahwa kepemimpinan, lingkungan kerja dan kompetensi dengan variabel intervening yaitu kepuasan kerja sebesar 83,9\% dan sisanya sebesar 16,1\% dijelaskan variabel lain diluar model penelitian, misal variabel kompensasi, komunikasi, loyalitas dan lain-lain. 
Korelasi antar variabel penelitian mempunyai hasil sebagai berikut:

a) Variabel Kepemimpinan dengan variabel Kinerja

Terdapat nilai 0,449 signifikan sehingga hubungan tersebut cukup kuat.

b) Variabel Lingkungan Kerja dengan variabel Kinerja

Terdapat nilai sebesar 0,490 signifikan sehingga hubungan tersebut cukup kuat.

c) Variabel Kompetensi dengan variabel Kinerja

Terdapat nilai sebesar 0,605 signifikan sehingga hubungan tersebut kuat.

d) Variabel Kepuasan Kerja dengan variabel Kinerja

Terdapat nilai sebesar 0,452 signifikan sehingga hubungan tersebut cukup kuat.

e) Variabel Kepemimpinan dengan variabel Kepuasan Kerja

Terdapat nilai sebesar 0,578 signifikan sehingga hubungan tersebut sangat kuat.

f) Variabel Lingkungan Kerja dengan variabel Kepuasan Kerja.

Nilai korelasinya sebesar 0,435 signifikan sehingga hubungan tersebut cukup kuat.

g) Variabel Kompetensi dengan variabel Kepuasan Kerja

Terdapat nilai 0,806 signifikan sehingga hubungan tersebut sangat kuat

Dapat dijelaskan bahwa pengaruh langsung merupakan pengaruh tanpa melalui variabel lain dari satu variabel independen ke variabel dependen. Pengaruh positif dan tidak signifikan dengan koefisien 0,166 sig 0,382 terdapat pada variabel kepemimpinan terhadap kinerja dengan memiliki korelasi atau hubungan $(0,449)$ signifikan yang cukup kuat; Lingkungan Kerja mempunyai pengaruh positif dan tidak signifikan terhadap kinerja dengan koefisien sebesar 0,280 sig 0,111 dan memiliki korelasi/ hubungan $(0,490)$ signifikan yang cukup kuat terhadap kinerja; Kompetensi mempunyai pengaruh positif dan signifikan terhadap kinerja dengan koefisien sebesar 0,633 sig 0,017 dan memiliki korelasi/ hubungan $(0,605)$ signifikan yang kuat terhadap kinerja.

Sedangkan pengaruh tidak langsung merupakan keadaan dimana variabel independen mempengaruhi variabel dependen melalui variabel lain yang disebut variabel intervening. Untuk kepemimpinan mempunyai pengaruh positif tidak signifikan terhadap kepuasan kerja, dan kepuasan kerja mempunyai pengaruh positif tidak signifikan terhadap kinerja dengan nilai koefisien sebesar $-0,059$; lingkungan kerja terhadap kepuasan kerja mempunyai pengaruh positif tidak signifikan, dan kepuasan kerja mempunyai pengaruh positif tidak signifikan dengan nilai koefisien sebesar - 0,018 terhadap kinerja; pengaruh positif signifikan juga terjadi pada variabel kompetensi terhadap kepuasan kerja; dan selanjutnya hubungan kepuasan kerja terhadap kinerja mempunyai pengaruh positif tidak signifikan dengan nilai koefisien sebesar $-0,185$.

Dapat dilihat dari analisis jalur bahwa jalur yang paling dominan jika dibandingkan jalur variabel lain dan berpengaruh langsung adalah variabel kompetensi. Atas dasar penelitian tersebut, kerangka konseptual akhir dari hubungan tiap variabel dapat digambarkan sebagai berikut:

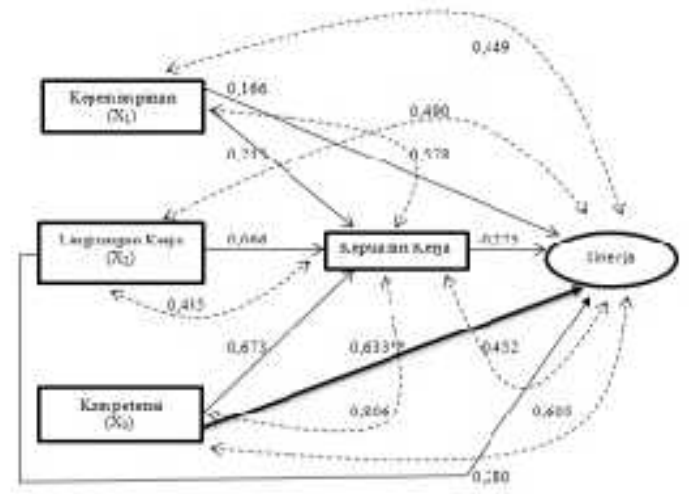




\section{PENUTUP}

\section{Kesimpulan}

Berdasarkan hasil analisis data dan pembahasan yang telah diuraikan dapat ditarik kesimpulan sebagai berikut:

1. Kepemimpinan mempunyai pengaruh positif dan tidak signifikan terhadap kepuasan kerja pegawai Sekolah Tinggi Pariwisata Sahid Surakarta.

2. Lingkungan kerja terhadap kepuasan kerja dari pegawai Sekolah Tinggi Pariwisata Sahid Surakarta mempunyai pengaruh positif dan tidak signifikan.

3. Kompetensi terhadap kepuasan kerja pada pegawai Sekolah Tinggi Pariwisata Sahid Surakarta mempunyai pengaruh positif dan signifikan.

4. Kepemimpinan mempunyai pengaruh positif dan tidak signifikan terhadap kinerja pegawai Sekolah Tinggi Pariwisata Sahid Surakarta.

5. Lingkungan kerja Sekolah Tinggi Pariwisata Sahid Surakarta mempunyai pengaruh positif dan tidak signifikan terhadap kinerja pegawainya.

6. Kompetensi mempunyai pengaruh positif dan signifikan terhadap kinerja pegawai Sekolah Tinggi Pariwisata Sahid Surakarta.

7. Kepuasan kerja mempunyai pengaruh negatif dan tidak signifikan terhadap kinerja pegawai Sekolah Tinggi Pariwisata Sahid Surakarta.

8. Terlihat dengan adanya analisis jalur yang paling dominan adalah pengaruh langsung dari variabel kompetensi.

\section{Saran}

Dalam menentukan kebijakan untuk meningkatkan perilaku kinerja pegawai dapat disarankan:

1. Jika kepemimpinan ditingkatkan maka kinerja pegawai Sekolah Tinggi Pariwisata Sahid Surakarta akan meningkat, meskipun hanya sedikit, oleh karena itu pimpinan pada Sekolah Tinggi Pariwisata Sahid Surakarta dapat melakukan langkah yang nyata sebagai berikut:

a. Pimpinan mempertahankan sikap untuk berperilaku kepada pegawai dengan memiliki jiwa keteladanan yang tinggi. Contohnya dengan bekerja tidak untuk kepentingan pribadi tetapi untuk kepentingan organisasi.

b. Pimpinan mempertahankan sikap untuk berperilaku kepada pegawai dengan memiliki rasa empati yang tinggi. Contohnya dengan memahami perasaan pegawai yang sedang sedih dan tetap memberi semangat dalam kondisi apapun.

c. Pimpinan mempertahankan sikap untuk berperilaku kepada pegawai dengan mau menerima masukan. Contohnya dengan membuka komunikasi yang baik terhadap ide atau gagasan yang disampaikan para pegawai untuk kemajuan organisasi.

2. Jika lingkungan kerja ditingkatkan maka kinerja pegawai Sekolah Tinggi Pariwisata Sahid Surakarta akan meningkat, meskipun hanya sedikit, oleh karena itu pimpinan pada Sekolah Tinggi Pariwisata Sahid Surakarta dapat melakukan langkah yang nyata sebagai berikut:

a. Pimpinan mempertahankan agar udara di tempat kerja sirkulasinya dapat lebih baik, dan membuat pegawai merasa lebih nyaman. Contohnya dengan tidak terlalu banyak barang menumpuk di sekitar tempat kerja.

b. Pimpinan mempertahankan agar temperatur udara di tempat kerja sejuk dan menyenangkan. Contohnya dengan memberi fasilitas $\mathrm{AC}$ dan pengharum ruangan di tiap ruang kerja. 
c. Pimpinan mempertahankan agar kebisingan/ suara ditempat kerja tidak mengganggu. Contohnya dengan menganjurkan penggunaan mesin atau peralatan kerja yang mempunyai tingkat kebisingan rendah.

3. Untuk meningkatkan kinerja pada pegawai Sekolah Tinggi Pariwisata Sahid Surakarta efektif melalui variabel kompetensi dengan melakukan langkah yang nyata sebagai berikut:

a. Pimpinan meningkatkan kemampuan pegawai untuk mengatasi masalah di lapangan. Contohnya pimpinan memberikan tugas luar kepada pegawai.

b. Pimpinan meningkatkan kemampuan pegawai dalam menyelesaikan tugas secara maksimal dan tepat waktu. Contohnya pimpinan memberikan pekerjaan dan target waktu dalam menyelesaikan suatu tugas.

c. Pimpinan meningkatkan kemampuan pegawai dalam bekerjasama dengan karyawan lain. Contohnya pimpinan menugaskan suatu pekerjaan pada beberapa pegawai agar dikerjakan dalam suatu team work.

4. Dalam penelitian selanjutnya, sebaiknya menggunakan sampel responden yang lebih besar sehingga akan didapatkan gambaran populasi yang lebih sebenarnya dan representatif.

5. Sebaiknya penelitian selanjutnya digunakan variabel yang berbeda misalnya menggunakan variabel kompensasi, komunikasi, loyalitas dan lain-lain.

6. Peneliti dapat mengembangkan penelitian ini dan dapat melakukan penelitian selanjutnya sehingga bermanfaat untuk ilmu pengetahuan.

7. Apabila akan menggunakan rujukan penelitian ini, sebaiknya karakteristik dan obyek penelitiannya pada bidang yang sama.

\section{DAFTAR PUSTAKA}

Ambar, dan Sulistiyani. (2004). Memahami Good Governance: Dalam Perspektif Sumber Daya Manusia. Yogyakarta: Penerbit Gava Media.

As'ad. (2008). Psikologi Industri. Yogyakarta: Libery

Basuki dan Susilowati. (2005). Dampak Kepemimpinan dan Lingkungan Kerja terhadap Semangat Kerja. Jurnal JRBI. Vol. 1, No. 1, Januari.

Dhermawan, Sudibya, Utama. (2012). Pengaruh Motivasi, Lingkungan Kerja, Kompetensi dan Kompensasi terhadap Kepuasan Kerja dan Kinerja Pegawai di Lingkungan Kantor Dinas Pekerjaan Umum Propinsi Bali, Jurnal Manajemen, Strategi Bisnis, dan Kewirausahaan. Vol. 6, No. 2, Hal: 173-184.

Gujarati, Damodar. (1997). EkonometrikaDasar. Alih Bahasa Sumarno Zain. Erlangga: Jakarta.

Hasibuan. (2001). Manajemen Sumber Daya Manusia. Jakarta: Bumi Aksara.

Handoko, T. Hani. (2010). Manajemen Personalia dan Sumberdaya Manusia. Edisi Kedua. Yogyakarta: BPFE - UGM

Handoko, T. Hani. (2002). Manajemen; Edisi Kedua, Cetakan Ke tiga belas. Yogyakarta: BPFE-UGM. 
Hardhiansyah dan Suprihadi. (2016). Pengaruh Kepemimpinan Transformasional, Lingkungan Kerja dan Kepuasan Kerja terhadap Kinerja Karyawan. Jurnal Ilmu dan Riset Manajemen : Volume 5, Nomor 12, Desember 2016

Irvianti, Prabowo, Permana. (2012). Pengaruh Budaya Organisasi, Kepemimpinan, Dan Motivasi Kerja Terhadap Kepuasan Kerja Karyawan Cv Surya Raya. Binus Business Review Vol. 3 No. 1 Mei 2012: $425-435$

Kartono, Kartini. (2005). Pemimpin dan Kepemimpinan. Jakarta: PT. Raja Grafindo Persada.

Karyadi, M. (2010). Kepemimpinan. Penerbit Karya Nusantara. Bandung.

Mangkunegara. (2001). Manajemen Sumber Daya Manusia Perusahaan. Remaja Rosdakarya. Bandung.

Mahsun, Mohamad. (2006). Pengukuran Kinerja Sektor Publik. Yogyakarta: BPFE.

Mangkunegara. (2005). Perilaku dan Budaya Organisasi. Cetakan Pertama. PT. Remaja Rosda Karya. Malang.

Mangkunegara. (2007). ManajemenSumberDayaManusia. Cetakan Ke Tujuh. PT. Remaja Rosda Karya. Bandung.

Moeheriono. (2009). Pengukuran Kinerja Berbasis Kompetensi. Bogor: Ghalia Indonesia.

Nawawi. (2004). Manajemen Sumber Daya Manusia Perusahaan. Bandung: Remaja Roosdakarya.

Nurwati, Nimram, Setiawan, Surachman. (2012). Pengaruh Kepemimpinan terhadap Budaya Organisasi, Komitmen Kerja, Perilaku Kerja dan Kinerja Pegawai (Studi pada Satuan Kerja Perangkat Daerah Propinsi Sulawesi Tenggara). Jurnal aplikasi manajemen Vol 10 no.1

Nitisemito, Alex.S. (2000). Manajemen Personalia. Jakarta: Ghalia Indonesia.

Pramana dan Sudarma. (2013). Pengaruh Kompensasi, Lingkungan Kerja Fisik dan Disiplin Kerja terhadap Kinerja Karyawan. e-jurnal Manajemen Unud, Bali

Posuma. (2013). Kompetensi, Kompensasi dan Kepemimpinan Pengaruhnya terhadap Kinerja Karyawan pada Rumah Sakit Ratumbuysang Manado. Jurnal EMBA. Vol.1 No.4, Desember 2013, Hal.646656

Prihadi, S. (2004). KinerjaAspek Pengukuran. PT. Gramedia Pustaka. Jakarta.

Robbins. (2006). Perilaku Organisasi. Edisi kesepuluh. PT Indeks Kelompok Gramedia. Jakarta.

Robbins. (2009). Manajemen. edisi 10, Jilid 2, (terjemahan Bob Sabran, dan Devri Bernadi Putera. 2010). Penerbit Erlangga, Jakarta.

Robbins. (2010). Perilaku Organisasi Buku 2. Salemba Empat. Jakarta.

Robbins. (2015). Perilaku Organisasi. Salemba Empat. Jakarta Selatan.

Rivai, Veitzal \& Sagala. (2011). Manajemen Sumber Daya Manusia untuk Perusahaan, Jakarta : PT Raja Grafindo Persada 
Rivai. (2004). ManajemenSumberDayaManusiaUntukPerusahaan: Dari Teori Ke Praktik. PT. Raja Grafindo Persada, Jakarta.

Suswardji dkk. (2012). Hubungan Kompetensi dan Disiplin Kerja Terhadap Kinerja Tenaga Kependidikan Universitas Singaperbangsa Kerawang. Jurnal Manajemen. Vol. 10 No. 1

Sofyandi. (2008). Manajemen Sumber Daya Manusia. Edisi Pertama, Penerbit Graha Ilmu, Yogyakarta.

Suprapta, Sintaasih, Riana. (2015). Pengaruh Kepemimpinan Terhadap Kepuasan Kerja Dan Kinerja Karyawan (Studi Pada Wake Bali Art Market Kuta-Bali). E-Jurnal Ekonomi dan Bisnis Universitas Udayana 4.06 (2015): 430-442

Sahlan, Mekel, Trang. (2015). Pengaruh Lingkungan Kerja, Kepuasan Kerja dan Kompensasi terhadap Kinerja Karyawan pada PT. Bank Sulut Cabang Airmadidi. Jurnal EMBA Vol.3 No.1, Hal. 52-62, Maret 2015

Sedarmayanti. (2001). Sumber Daya Manusia dan Produktivitas Kerja. Bandung: Mandar Maju.

Sedarmayanti. (2004). Pengembangan Kepribadian Pegawai. Penerbit MandarMaju. Bandung

Sedarmayanti. (2007). Manajemen Sumber Daya Manusia, Reformasi Birokrasi dan Manajemen Pegawai Negeri Sipil. Cetakan Pertama. Bandung: PT.Reflika Aditama.

Sedarmayanti. (2009). Sumber Daya Manusia dan Produktivitas Kerja. Penerbit: CV Mandar Maju. Bandung.

Sedarmayanti. (2018). ManajemenSumberDayaManusia: Reformasi Birokrasi dan Manajemen Pegawai Negeri Sipil. Jakarta: Reflika Aditama.

Simanjuntak, Payaman J. (2005). Manajemen dan Evaluasi Kerja. Jakarta: Lembaga Penerbit FEUI

Sutrisno, Edy. (2009). Manajemen Sumber Daya Manusia. Jakarta: Kencana Prenada Media Grup

Wibowo. (2007). Manajemen Kinerja. RajaGrafindopersada. Jakarta 